\title{
REVITALIZING SOCIAL SANCTIONS OF CUSTOMARY LAW TO ERODE PERMISSIVISM TOWARD CORRUPT BEHAVIOR IN SOCIETY ${ }^{1}$
}

\author{
Firman Freaddy Busroh \\ Sekolah Tinggi Ilmu Hukum Sumpah Pemuda \\ firmanbusroh@gmail.com
}

ARTICLE INFORMATION

Article history:

Received July 07, 2017

Revised Nov 05, 2017

Accepted Dec 16, 2017

JEL Classifications

K29; K49

\section{Key Words:}

Social sanction;

Permissivism;

Corrupt behavior.

DOI:

10.21532/apfj.001.17.02.02.01

\begin{abstract}
Corruption is still common in Indonesia. The existence of permissive culture in Indonesian society has caused corruption to continue to flourish and difficult to eradicate. Many cases of corruption have been brought to trial, but it is still unable reduce the level of corruption. Permissive culture (or also known as permissivism) is still often encountered in everyday life, such as granting bribes for administration, from office to religious affairs, such as marriage. The development of this permissive culture is due to the advancement of the times and the increasing lifestyle of hedonism in society which result in the community being consumptive. Unwittingly, the permissive culture has permitted corrupt behavior to occur. Corruption is an act that cannot be justified in any aspect. Corruption is detrimental to the State's finances which has an impact on the waiver of public interest. In addition, corruption also has a negative impact on various fields. So, corruption is an unforgivable act. Therefore, it is necessary to revitalize social sanction in combating the culture of corruption. Indonesia, as a legal laboratory, has various kinds of customary law. Customary law in Indonesia has traditional religious characteristics that use religious and cultural approaches. Some areas in Indonesia that still uphold the value of religion and customs can be used as a foundation to eradicate permissivism of corrupt behavior. In religion and custom there are social sanctions that can cause the feelings of shame for the perpetrators of corruption. Such social sanctions include exclusion, expulsion from a territory, or even the removal of a customary title. The revitalization of social sanctions could be part of a strategy for eradicating corruption in Indonesia.
\end{abstract}

1 The winner of National Call For Paper ACFE Indonesia Chapter 2017 


\section{INTRODUCTION}

Corruption seems to be a common case in Indonesia and its occurrence is very difficult to eradicate. Unfortunately some people still tolerate such a criminal act of corruption, although the losses incurred are very great. Related to this corrupt behavior, the Central Bureau of Statistics of Indonesia conducted a survey and released the results of the Anti Corruption Behavior Survey (SPAK) on February 22, 2016 in Jakarta. The results show that there are some behavioral indicators in society that lead to corrupt behavior ${ }^{2}$.

The behavioral indicators are divided into three scopes, that is, the scope of family, the scope of community and the scope of public. Corrupt behavior within the family still often occurs in the community, such as giving money to religious figures or community leaders. Only $36.32 \%$ of people consider that giving money or goods to these figures, when a family performing a celebration, is not fair, while $63.68 \%$ of people consider that the gift is fair. Giving money or goods is also often done during the religious holidays. Corrupt behavior commonly committed in the scope of public is giving money or collateral to family or colleagues in order for someone to become a civil servant or a private employee. Other example is giving bribes to speed up administrative matters such as the making of identity cards or family cards and so forth. In fact, only 62.28 percent of people consider that giving bribes for administrative matters is not fair while others consider that it is fair. In addition, other corrupt behaviors commonly done in the scope of public are giving compromise money to the police when violating traffic regulation, the officers of the Office of Religious Affair (KUA) who request additional money to transport to the location of the wedding, bailing out the teacher for

\footnotetext{
Published by Nabila Tashandra, http://nasional.kompas. com/read/2016/02/22/15204551/Ini.Perilaku. Koruptif.yang. Biasa.Terjadi.di.Lingkungan.Masyarakat, accessed on Juli 4, 2017 at $11: 41$
}

the child to be accepted into the school he teaches, distributing money and goods during the election, and so forth. The Anti-Corruption Behavior Survey has been conducted annually by the Central Bureau of Statistics (BPS) since 2012. In 2015 the survey was conducted in November and covered 33 provinces, 170 regencies / cities (49 cities and 122 regencies) with a sample of 10,000 households.

The corrupt behavior occurs because there are still some people who allow and forgive it. The small bad behavior will become habit and eventually change to a culture of corruption. Corrupt behavior arises because of a cultural shift in Indonesian society prioritizing the lifestyle of hedonism.

The era of globalization and modernization is the cause of the increasing lifestyle of hedonism. Hedonism is transformed into a view of life which considers that the ultimate goal of life is pleasure and enjoyment. For the believers of such view, they live their lives freely to fulfill an infinite passion. Along with the development of the times, hedonic lifestyle is increasingly rampant and poisoning the society, both young and old people. One of the examples is the spread of nightspots (discotheques), where from the young to the old come to spend time having fun, spending, gambling, drinking, committing adultery, and so on. The cost being spent is, of course, not small. In addition some people like to spend money to go to the shopping center to satisfy all their desires. The impact is the increased costs of living that ultimately lead to corrupt behavior.

Without any firm control, corrupt behavior will bring a broad impact to society. Just like a fire, small fire will change to blaze that can burn the whole region if there is no control over it. Therefore, serious efforts are necessary to erode the permissivism of corrupt behavior in society. 


\section{RESEARCH PROBLEM}

The problem discussed in this paper is the efforts on how to revitalize the social sanction of customary law to erode the permissivism of corrupt behavior in society.

\section{DISCUSSION}

Corruption eradication strategy consists of 2 (two) dimensions, preventive and repressive. Awareness of the need to eradicate corruption has encouraged the government to establish an anti-corruption agency called Corruption Eradication Commission (better known in Indonesia as KPK). KPK as a superbody institution was born in 2003 in the hope of eradicating corruption crime that continues to grow. Such a big hope raises the question of whether the KPK, established based on Law No. 30 of 2002, can effectively combat corruption crime that has been congregated, rooted and even cultured, or this nation has other alternatives to eradicate corruption.

Observing Law Number 30 of 2002, the spirit of the establishment of KPK is quite clear, that is, to eradicate corruption in extraordinary ways so that this institution is equipped with "advanced weapons" such as wide authority and independency in efforts to eradicate corruption.

KPK at least has handled a number of corruption cases that are in the spotlight of the wider community both nationally and internationally. KPK has disclosed several cases of corruption such as the case of corruption of helicopter procurement by Indonesian National Army in 2004, gratuity case conducted by KPPU member Mulyana W. Kusumah in 2005, the case of Governor of Bank Indonesia Aulia Pohan in 2008, who is the relative of former President of Indonesia Susilo Bambang Yudhoyono, until horrendous cases involving the law enforcement officers of the Attorney General's Office such as Urip Tri Gunawan, Artalyta Suryani and the tax evasion case of Gayus Tambunan. Judging from the cases that have been handled by KPK, almost all of the cases are difficult cases and cause the state suffered losses up to trillions of rupiah. In addition, a number of the Heads of Region have been imprisoned because of corruption case.

The label indicating that Indonesia is a corrupt country is still difficult to remove, which means that the eradication of corruption in Indonesia has not been able to decrease the number of corruption cases significantly. Indeed, in addition to KPK, there are other law enforcement agencies that have authority to handle corruption cases, such as police and prosecutors. However, conflicts often occur among the three law enforcement agencies.

In combating corruption, there should be understanding on the causes of corruption. One of the causes of corruption stems from allowing corrupt behavior to thrive in society. To combat corruption crime, law enforcement must be done comprehensively and cannot be partially. According to Soerjono Soekanto, the factors of law enforcement, among others, are:

1. Legal factor;

2. Law enforcer factor, that is, the parties who set up and apply the law;

3. Facility Factor that supports the law enforcement;

4. Community factor, that is, an environment in which the law is applicable or applied;

5. Culture Factor, that is, attainments, inventiveness, and sense based on human initiative in the social life. ${ }^{3}$

The above law enforcement factors stem from legal system theory of Friedman consisting of Legal Substance, Legal Structure, and Legal Culture. All three components of the law must support each other and be integrated so that the law becomes effective. For example, a legal substance cannot be enforced without the support of the legal structure and legal culture that propel it. On the contrary, the law is essentially an abstraction and determination /

\footnotetext{
Soerjono Soekanto, Faktor-faktor yang mempengaruhi penegakan hukum, Raja Grafindo Persada, Jakarta, 1983, page.32
} 
affirmation of norms in society. This normative picture is sociologically formulated in the sense of law enforcement as a process for realizing legal desires into reality ${ }^{4}$.

Thus, the state that must intervene in the realization of the law and the bodies that appear to be an independent organization essentially carry the same task of realizing law or enforcing the law in society.

Indonesia as a state of law (rechsstaat), as stated in the 1945 Constitution Post Amendment, has the principle of rules of law that must be upheld within the Republic of Indonesia. The principle of rules of law is nothing other than the rules of justice, that is, the law enforcement which is based on justice. Such a principle needs to be emphasized, since the discrimination in the application of the law, in fact, is still clearly visible. The legal product and its enforcement are more in favor of the ruling class, a society group that has economic power or political power on the other. The rights of the community in seeking justice, largely from the powerless groups, are always ruled out. The substantive or sociological justice is always enjoyed by those who are powerful. Meanwhile, the powerless just gets formal justice. Such a situation in a newly independent state is still understandable as it concerns the availability of human resources ${ }^{5}$.

The important factors in law enforcement are the factor of society and the factor of culture. The people of Indonesia are very heterogeneous, considering the pluralism as stated in the Unity in Diversity principle. Physically, Indonesian society consists of various tribes, religions, races and certain ethnic groups. Such condition, of course, will also affect law enforcement in Indonesia. Legal culture is the whole factor that determines how the legal system obtains its logical place

\footnotetext{
Satjipto Rahardjo, Op.Cit, page38

5 Satjipto Rahardjo.Masalah Penegakan Hukum, Sinar Baru,Bandung.1983, page109
}

within the framework of culture belonging to the general public.

The problem is that in Indonesia there is still permisivism of corrupt behavior that can hamper the eradication of corruption crime. Permisivism means allowing or permitting things or actions to occur. Permissivism is then able to develop into a habit and then become a culture.

The forms of permisivism of corrupt behavior in Indonesia include:

1. Giving transport money to marriage providers / religious leaders.

2. Giving money to help accelerate the administrative process in the agency.

3. Giving money if the project is granted.

4. Giving money so as to be accepted to be civil servants, law enforcement officers and other employees.

5. Giving money to guard officers in correctional institutions / prisons.

6. Giving money for room rent and even sex booths in prisons.

7. Receiving money, T-shirts and parcels from legislative candidates or candidates for regional head who are following the election.

The corrupt behavior mentioned above is often considered a small matter but gradually will become a habit. Unwittingly, the community has participated in making corrupt mental stay in the soul. We all together agree to combat and eradicate corruption, but in reality, people still consider the corrupt behavior is in a fairness stage and can be tolerated.

To erode the corrupt behavior requires ways that are derived from ethics and morals. The sources of ethics and morals are the religion and noble culture in which the authenticity is still preserved.

Religions and noble cultures that are still preserved have high honesty values. The values contained in religion and culture can be seen from the structure of their implementation 
in customary law. Customary law has traditional religious values that must be maintained. Customary law is the original law of Indonesia, in which there are order and prohibition inside. The prohibition in customary law implies social sanction received by perpetrators of crimes and offenses.

Indigenous peoples are an autonomous unit of society, in which they govern their life system (law, politics, social, and economy). The life system is born, developed and maintained by the society itself. According to Van Vollenhoven, in the territory of Indonesia, that is now called multicultural country, there are 19 areas of customary law (rechtsringen), such as customary law of 1.Aceh, 2. Gayo Alas Batak and Nias, 3.Minangkabau and Mentawai, 4.Sumatera Selatan and Enggano, 5.Melayu, 6.Bangka Balitung Kalimantan, 8.Minahasa, 9.Gorontalo, 10.Toraja, 11. Sulawesi Utara, 12. Ternate Islands, 13.Maluku, 14.Irian Barat, 15.Timor Islands, 16. Bali Lombok, 17. Central Java-East Java-Madura, 18.Solo-Yogyakarta, 19.Jawa Barat, Jakarta ${ }^{6}$.

The nine regions have their own peculiarities and customary laws. However, it can be concluded that the forms of social sanctions in customary laws include:

1. Being excluded and expulsed from a territory,

2. Being taunted and humiliated,

3. Payment of fines,

4. Indemnification and compensation,

5. The removal of a clan or title of custom,

6. Disposal somewhere

Social sanctions provided impact not only on the body and property, but also on his honor and his family. The impact is a shame that must be accepted by him and family. It is the feeling of a shame that becomes an important lesson for other people not to repeat it.

Social sanction is a part of Customary Criminal Law and cannot be separated from

\footnotetext{
6 Ade Saptomo, Hukum \& Kearifan Lokal, PT.Gramedia Wi-
} diasarana Indonesia, Jakarta,2010, hlm.13 the cultural aspect of Indonesia. Therefore, customary criminal law is a manifestation of Indonesian culture. Essentially, the culture has three embodiments: first, culture can manifest as a complex of ideas, values, and norms / rules; second, culture can manifest as a complex of human behavior activities in society; and third, culture can manifest as objects of human creation. $^{7}$

The nation's cultural value system consists of a concept that lives in the minds of most indigenous peoples that become part of the culture concerned, that is, about things that they should consider important and valuable in life.

Therefore, the cultural value system usually serves as a guide for doing things and as a system that controls the actions of human beings in society. In controlling the action, the community has a pattern to measure whether an action is good or bad, allowed or not by the community where the perpetrator lives and becomes a member of the community. ${ }^{8}$

Laws or legal norms, as guidelines for human beings to do or not to do, have legal consequences if the norms are not obeyed or violated. Each nation has its own law and, like a language, the law is alive and created by society because the law is the life of the nation itself. $^{9}$

The legal basis for the enactment of customary criminal law in the Dutch East Indies colonial period was regulated in the Law of article 131 I.S. jo A.B (Algemenn Bepalingen van Wetgeving). During the enactment of the Provisional Constitution of 1950, it was found several articles that could be used as the legal basis, such as: Article 32, Article 43 paragraph

\footnotetext{
Koentranigrat, Kebudayaan Mentalitet dan Pembangunan, PT Gramedia, Jakarta, 1974, page15

8 Hermin Hadiati Koeswadji, Aspek Budaya Dalam Pemidanaan Delik Adat, Makalah dalam Simposium Pengaruh Kebudayaan/Agama Terhadap Pidana, Fakultas Hukum dan Pengetahuan Masyarakat Universitas Udayana, Denpasar,1975, page 9 Ibid. page. 6
} 4 
(4), Article 104 paragraph (1), Article 14 paragraph (3), and Article 16 paragraph (2). But, actually it was not necessary to take the legal basis derived from the provisions of the law, because the existence of customary law is the original law and the original thing is valid by itself, unless there are things that hinder its enactment. ${ }^{10}$

Furthermore, the legal basis for the enactment of customary law can be seen in Article 5 paragraph (3) sub b of Emergency Law Number 1 of 1951 LN Number 51-9 on temporary measures to organize the Unity of Structure, Power and Events of Civil Courts. In the article it can be seen that actual social sanction of customary law is the main sanction in the case of deeds which according to the living law are considered as the deeds that can be punished, but there is no appeal in the Criminal Code. ${ }^{11}$

Van Vollenhouven elaborated that in Adatrecht, Chapter XI (Adat strafrecht van Indonesiers $\mathrm{p} 745$ ) there were major differences between the legal system of the former Criminal Code and the traditional criminal law system, such as: ${ }^{12}$

1. A basic principle of the Criminal Code is that what can be convicted is a human only. This means that the village, relatives, or family do not have criminal responsibility against the bad action committed by a citizen. Whereas in certain areas, when a person commits a crime, the criminal's relatives are required to bear the punishment imposed for a crime committed by the person.

2. The second basic principle of the Criminal Code is that a person can only be punished if his actions are committed

\footnotetext{
10 Sudarto, Hukum Pidana I, Yayasan Sudarto, Semarang, 1990, page 17

11 Nyoman Serikat Putra Jaya, Relevansi Hukum Pidana Adat dalam Pembaharuan Hukum Pidana Nasional, PT Citra Aditya Bakti, Bandung , 2005, page 41

12 Surojo Wignjodipuro, Pengantar dan Asas-Asas Hukum Adat, Alumni, Bandung, 1979, page 298
}

intentionally or negligently. Whereas in customary criminal law, the element of error is not an absolute requirement, sometimes it does need any evidence of intent or error

3. The Criminal Code System recognizes and distinguishes the problem of assisting in committing a crime, persuasion, and participation in article 55 and article 56. Whereas in the customary law system, any person who opposes the rule of customary law is required to participate in the business required to restore legal balances.

4. The Criminal Code System sets the trial as a criminal act in article 53. Meanwhile, in the customary law system does not convict a person for trying to do offense

5. The Criminal Code system is based on the system of prae existence regels (predetermined violation of law). Customary law is not familiar with the system of prae existence regels. In customary law the customary offense is not static, meaning that it is not fixed throughout the entire period as a customary offense. Each customary law arises, develops, and then disappears with the birth of a new customary law.

Each community or group wants its norms to be obeyed, but not everyone can and will obey. In order for their norms to be obeyed, the community or group gives sanction or amplifier. The terms given by Prof. Djojodigoeno as "pekokoh". Sanctions can be positive for those who obey the norm. Negative sanctions can be criminal sanctions, while positive sanctions can be rewards. In addition, there are still more distinctions such as formal sanctions coming from the state and informal sanctions coming from the community. ${ }^{13}$

Likewise, the criminal law also contains the rules. Maintaining the rules needs to be

\footnotetext{
13 Sudarto, Hukum dan Hukum Pidana, Penerbit Alumni,
} Bandung, 1986, page 29 
supported by a sanction. Sanctions against offenders of customary law norms are called customary sanctions. This customary sanction is a social sanction that can be applied and revitalized in addition to other sanctions such as criminal, civil and administrative sanctions.

The sustainability of customary law which is still preserved maintained well has high ethical and moral values. For this reason the government needs to revitalize the values of customary law in society as part of the strategy to eradicate corruption.

\section{CONCLUSION}

Corruption eradication strategy consists of 2 (two) dimensions, that is, preventive dimension and repressive dimension. The criminal act of corruption starts from by allowing corrupt behavior to grow and develop. To combat corruption, law enforcement must be done comprehensively, not partially.

The problem is that in Indonesia there is still permisivism in society toward corrupt behavior that can hamper the eradication of corruption crime. Permisivism means to allow things or actions to happen. It is the permissivism that gradually develops into a habit and then become a culture.

To erode the behavior requires ways that are derived from ethics and morals. The sources of ethics and morals are religion and noble culture in which their sustainability are still preserved well. Religions and noble cultures that are still preserved well have high honesty values. The values contained in religions and cultures can be seen from the structure of their implementation in customary law. Customary Law has traditional religious values, that is, the values that must be maintained. Customary Law is the original law of Indonesia containing order and prohibition. The prohibition in customary law implies social sanction received by perpetrators of crimes and offenses.

The forms of social sanction in customary law are
1. Being excluded and expulsed from a territory,

2. Being taunted and humiliated,

3. Payment of fines,

4. Indemnification and compensation,

5. The removal of a clan or customary title,

6. Disposal somewhere

The social sanctions provided impact not only on the body and property, but also on his honor of and his family. The impact is a shame that must be accepted by him and his family. It is the shame that becomes an important lesson for other people not to repeat it.

Customary law, in which its sustainability is still preserved and maintained well, has high ethical and moral values. For this reason the government needs to revitalize the values of customary law in society as part of the strategy to eradicate corruption.

\section{REFERENCES}

Ade Saptomo, Hukum \& Kearifan Lokal, PT.Gramedia Widiasarana Indonesia, Jakarta, 2010

Hermin Hadiati Koeswadji, Aspek Budaya Dalam Pemidanaan Delik Adat, Makalah dalam Simposium Pengaruh Kebudayaan/ Agama Terhadap Pidana, Fakultas Hukum dan Pengetahuan Masyarakat Universitas Udayana, Denpasar,1975

Koentranigrat, Kebudayaan Mentalitet dan Pembangunan, PT Gramedia, Jakarta, 1974

Nyoman Serikat Putra Jaya, Relevansi Hukum Pidana Adat dalam Pembaharuan Hukum Pidana Nasional, PT Citra Aditya Bakti, Bandung , 2005

Satjipto Rahardjo. Masalah Penegakan Hukum, Sinar Baru,Bandung. 1983

Soerjono Soekanto, Faktor-faktor yang mempengaruhi penegakan hukum, Raja Grafindo Persada, Jakarta, 1983

Sudarto, Hukum Pidana I, Yayasan Sudarto, Semarang, 1990 
Sudarto, Hukum dan Hukum Pidana, Penerbit Alumni, Bandung, 1986

Surojo Wignjodipuro, Pengantar dan AsasAsas Hukum Adat, Alumni, Bandung, 1979

\section{Internet Site}

Published by Nabila Tashandra, http://nasional. kompas.com/read/2016/02/22/15204551/ Ini.Perilaku. Koruptif.yang.Biasa.Terjadi. di.Lingkungan.Masyarakat, accessed on July 4, 2017 at 11:41 